\title{
Dynamics of chromosomal aberrations, induction of apoptosis, BRCA2 degradation and sensitization to radiation by hyperthermia
}

\author{
JUDITH W.J. BERGS ${ }^{1,2}$, ARLENE L. OEI ${ }^{1}$, ROSEMARIE TEN CATE ${ }^{1}$, HANS M. RODERMOND ${ }^{1}$, \\ LUKAS J. STALPERS ${ }^{1}$, GERRIT W. BARENDSEN ${ }^{1}$ and NICOLAAS A.P. FRANKEN ${ }^{1}$ \\ ${ }^{1}$ Laboratory for Experimental Oncology and Radiobiology (LEXOR), \\ Center for Molecular Medicine, Department of Radiation Oncology, Academic Medical Center, \\ University of Amsterdam, 1100 DE Amsterdam, The Netherlands
}

Received August 11, 2015; Accepted April 5, 2016

DOI: $10.3892 /$ ijmm.2016.2611

\begin{abstract}
Hyperthermia can transiently degrade BRCA2 and thereby inhibit the homologous recombination pathway. Induced DNA-double strand breaks (DSB) then have to be repaired via the error prone non-homologous end-joining pathway. In the present study, to investigate the role of hyperthermia in genotoxicity and radiosensitization, the induction of chromosomal aberrations was examined by premature chromosome condensation and fluorescence in situ hybridisation (PCC-FISH), and cell survival was determined by clonogenic assay shortly $(0-1 \mathrm{~h})$ and $24 \mathrm{~h}$ following exposure to hyperthermia in combination with ionizing radiation. Prior to exposure to $4 \mathrm{~Gy} \gamma$-irradiation, confluent cultures of SW-1573 (human lung carcinoma) and RKO (human colorectal carcinoma) cells were exposed to mild hyperthermia $\left(1 \mathrm{~h}, 41^{\circ} \mathrm{C}\right)$. At $1 \mathrm{~h}$, the frequency of chromosomal translocations was higher following combined exposure than following exposure to irradiation alone. At $24 \mathrm{~h}$, the number of translocations following combined exposure was lower than following exposure to irradiation only, and was also lower than at $1 \mathrm{~h}$ following combined exposure. These dynamics in translo-
\end{abstract}

Correspondence to: Dr Nicolaas A.P. Franken, Laboratory for Experimental Oncology and Radiobiology (LEXOR), Center for Molecular Medicine, Department of Radiation Oncology, Academic Medical Center, University of Amsterdam, P.O. Box 22700, 1100 DE Amsterdam, The Netherlands

E-mail: n.a.franken@amc.uva.nl

Present address: ${ }^{2}$ German Cancer Research Center (DKFZ), Heidelberg; Partner site Frankfurt am Main; Member of the German Consortium for Translational Cancer Research (DKTK); Clinic for Radiotherapy and Oncology, Molecular Radiobiology, University Hospital Frankfurt, Goethe University, Theodor-Stern-Kai 7, 60590 Frankfurt am Main, Germany

Key words: hyperthermia, chromosomal translocations, chromosomal fragments, premature chromosome condensation and fluorescence in situ hybridisation, cell survival, linear quadratic-model cation frequency can be explained by the hyperthermia-induced transient reduction of BRCA2 observed in both cell lines. In both cell lines exposed to radiation only, potentially lethal damage repair (PLDR) correlated with a decreased number of chromosomal fragments at $24 \mathrm{~h}$ compared to $1 \mathrm{~h}$. With combined exposure, PLDR did not correlate with a decrease in fragments, as in the RKO cells at $24 \mathrm{~h}$ following combined exposure, the frequency of fragments remained at the level found after $1 \mathrm{~h}$ of exposure and was also significantly higher than that found following exposure to radiation alone. This was not observed in the SW-1573 cells. Cell survival experiments demonstrated that exposure to hyperthermia radiosensitized the RKO cells, but not the SW-1573 cells. This radiosensitization was at least partly due to the induction of apoptosis, which was only observed in the RKO cells and which may have been induced by BRCA2 degradation or different types of chromosomal aberrations. An important observation of this study is that the genotoxic effect of hyperthermia shortly after combined epxosure (to hyperthermia and radiation) is not observed at $24 \mathrm{~h}$ after treatment.

\section{Introduction}

Hyperthermia has been shown to be a potent radiosensitizer. It has been suggested that the inhibition of DNA repair is one of the sensitization mechanisms (1). Indeed, it has recently been shown that BRCA2, a protein of the homologous recombination (HR) (2) pathway is a target of hyperthermia (3). Following exposure to ionizing radiation, it can take several hours to complete DNA damage repair. This depends on the repair mechanisms, the error-prone NHEJ or the error-free HR pathway. These pathways can compete with each other $(4,5)$ in the late $\mathrm{S}$ - or G2-phase. This is due to the fact that HR is only active in the late S- and G2-phase, and not in the G0- or G1-phase. As hyperthermia transiently degrades BRCA2, and thereby inhibits the HR pathway, double-strand break (DSB) repair may be directed to the error-prone NHEJ pathway $(4,5)$. In a previous study, using the comet assay and micronucleus test, it was demonstrated that exposure to hyperthermia alone at $42-48^{\circ} \mathrm{C}$ for 30-120 min induced genotoxic effects in human cells (6). With premature chromosome condensation and fluorescence 
in situ hybridisation (PCC-FISH) it was also previously shown that the combined exposure to mild hyperthermia $\left(1 \mathrm{~h}, 41^{\circ} \mathrm{C}\right)$ and ionizing radiation induced an increase in the frequency of chromosomal translocations as compared to exposure to radiation alone shortly following exposure (7).

The interaction between hyperthermia and ionizing radiation most likely results from the inhibition of the repair of radiationinduced DNA damage by exposure to heat $(8,9)$. Tomita $(8)$ stated that when DNA is not repaired or is misrepaired following combined exposure to radiation and hyperthermia, cells undergo apoptosis or apoptosis is induced. In a previous study, using gel electrophoresis combined with a restriction digestion assay and Southern hybridisation, it was demonstrated that hyperthermia increases the probability of DNA DSBs being incorrectly rejoined (10). Non-rejoined, as well as misrejoined DSBs are potentially lethal for a cell. It has been found that the amount of residual DNA damage studied with gel electrophoresis (11) and PCC-FISH (12) correlated with a decrease in clonogenic survival following combined exposure to hyperthermia and irradiation $(11,12)$. Dewey et al (13) studied metaphases following colcemid treatment, and showed that hyperthermia not only increased the number of radiation-induced chromosomal breaks, but also the frequency of chromosomal exchanges, and suggested that hyperthermia may promote misrepair. Bergs et al (7), using PCC-FISH and foci analyses, demonstrated that the increased induction of chromosomal translocations following combined exposure to hyperthermia $\left(1 \mathrm{~h}, 41^{\circ} \mathrm{C}\right)$ and ionizing radiation may be due to the inhibition of HR. In this study, an increased frequency of chromosomal translocations was also observed in mutant cells deficient for RAD54, one of the proteins involved in HR repair. Krawczyk et al (3) demonstrated that the inhibition of recombination repair via the transient degradation of the BRCA2 protein lasts for only $6 \mathrm{~h}$. All these studies were performed shortly following exposure. It would therefore be of interest to study the chromosomal aberration frequency following combined exposure to hyperthermia followed by ionizing radiation beyond that time period.

In the present study, the induction of chromosomal damage by combined exposure to hyperthermia and radiation was investigated at $24 \mathrm{~h}$ following exposure and compared with the damage frequencies at $1 \mathrm{~h}$ following exposure in two different human tumor cell lines (SW-1573 and RKO). To examine chromosomal aberrations, the PCC-FISH technique was used, as previously described (14). The advantage of using the PCC technique is that chromosomal aberrations can be examined shortly following exposure. Survival curves were analysed according to the linear-quadratic (LQ) model S(D)/ $\mathrm{S}(0)=\exp -\left(\alpha \mathrm{D}+\beta \mathrm{D}^{2}\right)$, as previously described (15-19). Using the LQ model, changes in potentially lethal damage repair (PLDR) can be determined quantitatively by the analysis of the linear parameter $\alpha$, describing the low-dose range of the survival curve, separately from the parameter $\beta$ dominating the high-dose range $(17,19)$. Furthermore, the effects of hyperthermia on the BRCA 2 protein and the induction of apoptosis were examined as the possible mechanisms of radiosensitization.

\section{Materials and methods}

Cell culture. The human squamous lung carcinoma cell line, SW-1573, was grown in Leibowitz-15 medium (Gibco-BRL
Life Technologies, Breda, The Netherlands) supplemented with $10 \%$ fetal bovine serum (FBS) and $2 \mathrm{mM}$ glutamine. The cells were maintained at $37^{\circ} \mathrm{C}$ in an incubator with humidified air without additional $\mathrm{CO}_{2}$. The doubling time of these cells during exponential growth is approximately $24 \mathrm{~h}(20,21)$. The human colon cancer cell line, RKO, was grown in McCoy's 5A medium with $25 \mathrm{mM}$ HEPES (Gibco-BRL Life Technologies) supplemented with $10 \% \mathrm{FBS}$ and $2 \mathrm{mM}$ glutamine. The cells were maintained at $37^{\circ} \mathrm{C}$ in an incubator with humidified air supplemented with $5 \% \mathrm{CO}_{2}$. Both cell lines (obtained from ATCC, Wesel, Germany) express wild-type (wt) p53, as can be observed in Fig. 1 which shows the induction of p53 at $4 \mathrm{~h}$ following exposure to hyperthermia, 4 Gy radiation and combined exposure to hyperthermia and radiation. The doubling time of these cells during exponential growth is approximately $24 \mathrm{~h} \mathrm{(22).} \mathrm{All} \mathrm{experiments} \mathrm{were} \mathrm{performed}$ using confluent cell cultures. Confluent cultures of RKO cells consisted of $31.2 \pm 4.7 \%$ cells in the G0/G1-phase, $50.1 \pm 4.6 \%$ in the $\mathrm{S}$-phase and $18.7 \pm 3.8 \%$ cells in the G2/M-phase, as previously determined by BrdU labeling and flow cytometry (22). Confluent cultures of SW-1573 cells contained $39.6 \pm 4.7 \%$ cells in the G0/G1-phase, $48.7 \pm 5.8 \%$ in the S-phase and $11.7 \pm 7.9 \%$ cells in the G2/M-phase, as previously determined (23).

Clonogenic assay and the LQ model. Clonogenic assays using the SW-1573 and RKO cells were conducted as previously described by Franken et al (24). For radiation survival curves, the cells were irradiated with or without prior exposure to hyperthermia for $1 \mathrm{~h}$ at $41^{\circ} \mathrm{C}$. To investigate PLDR, the cells were plated immediately [immediately plated (ip)] and at $24 \mathrm{~h}$ [delayed plated (dp)] following exposure. The correlation between hyperthermia-induced radiosensitization and the induction of chromosomal damage, and the correlation between PLDR and the induction of chromosomal aberrations were investigated. Surviving fractions $[S(D) / S(0)]$ after radiation dose (D) were corrected for the toxicity of hyperthermia alone and survival curves were analysed to calculate values of the linear and quadratic parameters $\alpha$ and $\beta$, using SPSS 14.0 statistical software (SPSS, Inc., Chicago, IL, USA) by means of a fit of the data by weighted linear regression, according to the LQ formula: $S(D) / S(0)=\exp -\left(\alpha D+\beta D^{2}\right)$, as previously described (15-19). This equation provides a useful description of experimentally determined survival curves. Parameter $\alpha$ can be interpreted to represent damage induced by single track lethal damage, and parameter $\beta$ represents the frequency of sublethal damage induced by two separate tracks. Potentially lethal damage is assumed to represent a part of the term $\alpha \mathrm{D}$, as well of $\beta D^{2}(17,19)$. From the values of the LQ parameters, the enhancement factors and the PLDR value are calculated: $\alpha$-EF, enhancement factor $\alpha$ for hyperthermia (ratio of value of $\alpha_{\mathrm{ht}}$ and $\alpha$ ); $\beta$-EF, enhancement factor $\beta$ for hyperthermia (ratio of value of $\beta_{\mathrm{ht}}$ and $\beta$ ); PLDR- $\alpha$, potentially lethal damage repair $\alpha$ (ratio of value of $\alpha_{\text {ip }}$ and $\alpha_{\mathrm{dp}}$ ); PLDR- $\beta$ potentially lethal damage repair $\beta$ (ratio of value of $\beta_{\mathrm{ip}}$ and $\beta_{\mathrm{dp}}$ ).

Irradiation. Irradiation treatments were performed on confluent cell cultures with single doses of $\gamma$-rays from a ${ }^{137} \mathrm{Cs}$ source at a dose rate of approximately $0.5 \mathrm{~Gy} / \mathrm{min}$. For clonogenic assays, complete survival curves were obtained and the 

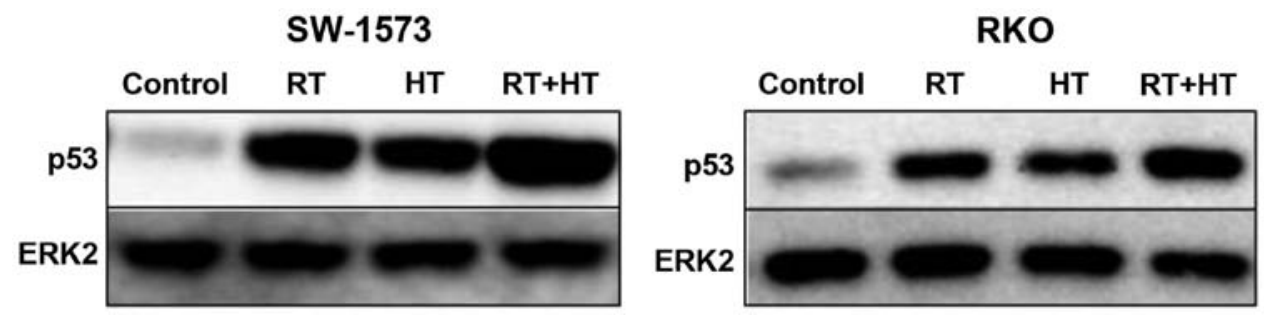

Figure 1. Induction of p53 at $4 \mathrm{~h}$ following exposure to hyperthermia, 4 Gy radiation or combined exposure to hyperthermia and radiation, demonstrating that p53 is expressed in both cell lines studied. Control, unexposed cells; RT, radiation, HT, hyperthermia.

cells were irradiated with a single dose of $0,2,4,6$ and 8 Gy. For chromosomal aberration, apoptosis and cell cycle analysis, the cells were irradiated with a single dose of $4 \mathrm{~Gy}$.

Hyperthermia. The incubation of the cells at $41^{\circ} \mathrm{C}$ for $1 \mathrm{~h}$ was performed by submerging the Petri dishes in a thermostatically controlled waterbath (Lauda aqualine AL 12; Beun de Ronde, Abcoude, The Netherlands) for $1 \mathrm{~h}$. The temperature was checked in parallel dishes and the desired temperature $\left( \pm 0.1^{\circ} \mathrm{C}\right)$ was reached in approximately $5 \mathrm{~min}$. The atmosphere of the waterbath was adjustable by a connection with air and $\mathrm{CO}_{2}$ supplies. The RKO cells were heated in a $5 \% \mathrm{CO}_{2} / 95 \%$ air atmosphere with an air inflow of $21 / \mathrm{min}$. The SW-1573 cells do not require additional $\mathrm{CO}_{2}$. In the case of combination experiments, the cells were exposed to hyperthermia for $1 \mathrm{~h}$ immediately prior to irradiation.

PCC-FISH and scoring of chromosomal aberrations. To examine chromosomal fragments and translocations, confluent cultures of SW-1573 and RKO cells were used. For the induction of prematurely condensed chromosomes (PCCs), the cells were incubated for $1 \mathrm{~h}$ with $80 \mathrm{nM}$ of calyculin A at $1 \mathrm{~h}$ or at $24 \mathrm{~h}$ following exposure to hyperthermia and/ or radiation (14). Preparations were obtained by a standard cytogenetic technique. The visualization of chromosomes was accomplished by FISH. The chromosomal spreads were hybridized to whole-chromosome FISH probes (Metasystems, Altlussheim, Germany). In the SW-1573 cells, a probe for chromosome 2 was used. The SW-1573 cells contain 3 intact copies of chromosome 2 and contain approximately $7.8 \%$ of the genome $(23,25)$. In the RKO cells, chromosome 18 was studied as the cells contain 2 intact copies of this chromosome and contain approximately $2.5 \%$ of the genome (22). The slides were counterstained with a mixture $(1: 1, \mathrm{v} / \mathrm{v})$ of 4',6-diamidino-2-phenylindole (DAPI; $2.5 \mu \mathrm{g} / \mathrm{ml}$ ) and anti-fade solution (Vectashield; Vector Laboratories, Burlingame, CA, USA). The slides were examined under a fluorescence microscope (Axioscop 2; Zeiss, Jena, Germany) with suitable filter combinations (DAPI, FITC, Cy3 and a FITC/Cy3 combination) equipped with a Jenoptik (Jena, Germany) ProgRes ${ }^{\circledR}$ MF CCD camera. Translocations and fragments of painted chromosomes were scored as described earlier $(7,26,27)$ using Isis 5.3 from MetaSystems (Altlussheim, Germany). For a comparison of the number of chromosomal aberrations using different chromosomes, corrections were made for both the copy number and size of the chromosomes. In the figures, the frequency of total translocations/cell and the total number of fragments corrected for the complete genome is presented.
Western blot analysis for p53 and BRCA2. The controls and treated cells were harvested at different time-points after treatment. Pellets were lysed in ice-cold RIPA buffer $(20 \mathrm{mM}$ Tris-HCl, $150 \mathrm{mM} \mathrm{NaCl}, 1 \mathrm{mM} \mathrm{Na}$ EDTA, 1\% NP-40, $1 \%$ sodium deoxycholate, $2.5 \mathrm{mM}$ sodium pyrophosphate, $1 \mathrm{mM} \beta$-glycerophosphate, $1 \mathrm{mM} \mathrm{Na} \mathrm{VO}_{4}$ and $1 \mu \mathrm{g} / \mathrm{ml}$ leupeptin) for $30 \mathrm{~min}$ on ice with protein inhibitors, as previously described (28). Laemmli buffer with 2-mercaptoethanol $(355 \mathrm{mM})$ was added to the supernatant $(1: 1)$ and heated in boiling water for 2-5 min. Finally, the samples were sonificated (Sonics and Materials, Inc., Newtown, CT, USA). Protein $(1 \mu \mathrm{g})$ was resolved by $10 \%$ SDS-PAGE precast gels (Bio-Rad Laboratories, Hercules, CA, USA) and transferred onto PVDF membranes. Equal protein loading was checked by Ponceau S staining (28). Immunodetection was performed for BRCA2 mAb (antibodies-online.com, lot: a115912) in combination with a horseradish peroxidase-conjugated secondary anti-mouse IgG (1031-05; Southern Biotech, Birmingham, AL, USA). The housekeeping protein, ERK2, was detected using mAb (Bethyl Laboratories, Montgomery, TX, USA) and a secondary anti-rabbit $\mathrm{mAb}$ (Invitrogen Life Technologies, Carlsbad, CA, USA). All samples were enhanced using chemoluminescence (Amersham Pharmacia Biotech, Piscataway, NJ, USA). Finally, the blots were analysed using the LAS4000 biomolecular imager (GE Healthcare Healthcare Europe $\mathrm{GmbH}$, Eindhoven, The Netherlands).

Apoptosis. Apoptosis was examined in confluent cultures of RKO and SW-1573 cells following $1 \mathrm{~h}$ of exposure at $41^{\circ} \mathrm{C}$ hyperthermia alone, following exposure to radiation (4 Gy) alone, or following combined exposure to hyperthermia and radiation using the method described in the study by Riccardi and Nicoletti (29). At 1 and $24 \mathrm{~h}$ following exposure, the cells were collected and pellets were resuspended in Nicoletti buffer $(0.1 \% \mathrm{w} / \mathrm{v}$ sodium citrate, $0.1 \% \mathrm{v} / \mathrm{v}$ Triton X-100, $50 \mathrm{mg} / \mathrm{ml}$ propidium iodide in distilled water, $\mathrm{pH}$ 7.4). Analyses were carried out using a flow cytometer (FACSCanto; BectonDickinson Biosciences, San Jose, CA, USA).

\section{Results}

Effect of exposure to hyperthermia on the number of chromosomal aberrations. Images of examples of the studied PCCs are presented in Fig. 2; however, chromatid-type aberrations were rarely observed. The effects of hyperthermia and radiation on the induction of chromosomal translocations in the SW-1573 and RKO cells are presented in Fig. 3. Exposure to hyperthermia $\left(41^{\circ} \mathrm{C}\right.$ for $\left.1 \mathrm{~h}\right)$ alone did not increase the number 


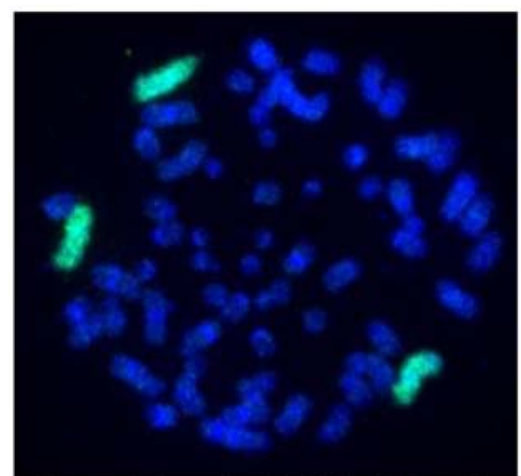

Normal situation in SW-1573 cells

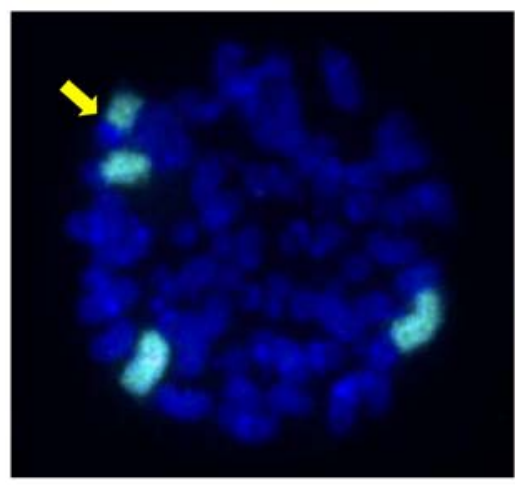

Translocation at arrow

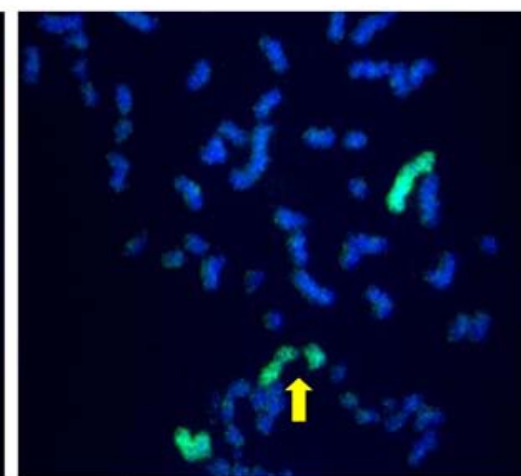

Fragments at arrow

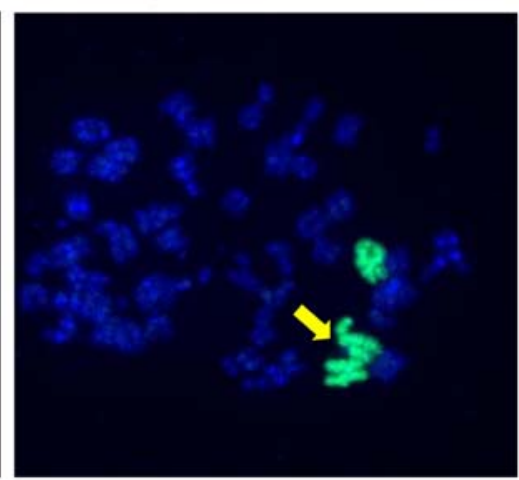

Chromatid type aberration at arrow

Figure 2. Images showing typical examples of chromosome- and chromatid-type aberrations in the studied prematurely condensed chromosomes (PCCs) in SW-1573 cells. Chromatid-type aberrations were rarely observed.

of translocations at 1 or $24 \mathrm{~h}$ following exposure compared to the unexposed cells (Fig. 3). At $1 \mathrm{~h}$ following exposure to irradiation alone, a slight increase in the number of translocations compared to the untreated samples was observed. More chromosomal translocations were observed at $24 \mathrm{~h}$ than at $1 \mathrm{~h}$ after irradiation. At $1 \mathrm{~h}$ following combined exposure to radiation and hyperthermia, the number of translocations was higher than following exposure to irradiation alone (Fig. 3A). However, at $24 \mathrm{~h}$ following combined exposure, the number of translocations was lower than after radiation alone (Fig. 3B).

At $1 \mathrm{~h}$ following exposure to hyperthermia alone, in the SW-1573 cells, an increase in the frequency of chromosomal fragments as compared to the unexposed cells was observed (Fig. 4A). Exposure to radiation at 4 Gy increased the number of chromosomal fragments in both cell lines compared to the unexposed cells or exposure to hyperthermia alone (Fig. 4A). In the RKO cells, slightly more fragments were found than in the SW-1573 cells; however, this difference was not significant at $1 \mathrm{~h}$ following combined exposure or following exposure to radiation alone. In both cell lines, no significant differences in the number of chromosomal fragments were found following combined exposure to hyperthermia and radiation, as compared to exposure to radiation alone (Fig. 4). At $24 \mathrm{~h}$ following exposure to $4 \mathrm{~Gy}$ radiation or combined exposure, the number of fragments was lower than after $1 \mathrm{~h}$ in both cell lines. Following combined exposure, significantly more fragments were found in the RKO cells than in the SW-1573 cells (Fig. 4B). At $4 \mathrm{~h}$ following exposure, the results of chromosomal aberrations did not differ from the results obtained at the $1 \mathrm{~h}$ time-point (data not shown). However, the difference in the number of translocations following combined exposure compared to exposure to radiation alone was not significant.

Effect of pre-exposure to hyperthermia on clonogenic cell survival following the exposure of $S W-1573$ and RKO cells to ionizing radiation. To determine whether exposure to mild hyperthermia $\left(41^{\circ} \mathrm{C}\right)$ can enhance cellular radiosensitivity, clonogenic assays were conducted. Exposure of the cells to hyperthermia $(1 \mathrm{~h}$, $41^{\circ} \mathrm{C}$ ) alone had minimal effects and resulted in a surviving fraction of $0.8 \pm 0.4$ in the ip cells and of $0.9 \pm 0.1$ in dp cells for both cell lines. In the SW-1573 cells (Fig. 5A and B), exposure to hyperthermia at $41^{\circ} \mathrm{C}$ resulted in a modest radiosensitization. This was due to an effect on the quadratic parameter $\beta$ (Table I). Pre-exposure of the RKO cells to hyperthermia for $1 \mathrm{~h}$ at $41^{\circ} \mathrm{C}$ significantly enhanced cellular radiosensitivity both in the ip and dp cells (Fig. 5C and D). Calculations with the LQ model showed that this was due to an increase in both the linear parameter $\alpha$ and the quadratic parameter $\beta$ (Table I). The clonogenic survival of the cells at $24 \mathrm{~h}$ following irradiation was higher than the survival of the cells plated immediately after irradiation (Fig. 5). This is most clear from the values of PLDR, which for $\alpha$ are all higher than 1 and for some of the $\beta$ 's where the PLDR values are higher than 1 (Table I).

Effect of hyperthermia on BRCA2. The effect of hyperthermia on the BRCA2 levels were examined by western blot analysis (Fig. 6). A clear decrease in the BRCA2 protein level was observed for up to $5 \mathrm{~h}$ following exposure to hyperthermia. In the RKO cells, BRCA2 was almost completely degraded, while in the SW-1573 cells, BRCA2 could still be detected. However, 
A $1 \mathrm{~h}$ after irradiation

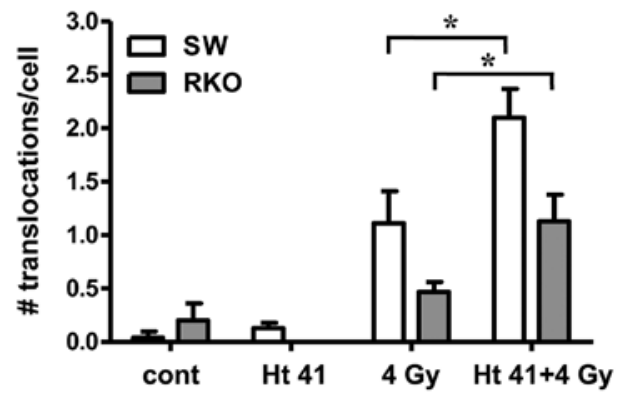

B

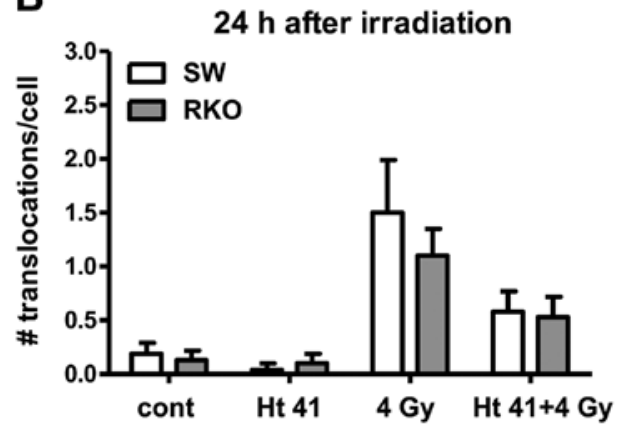

Figure 3. Frequency of translocations in SW-1573 (chromosome 2) and RKO (chromosome 18) cells. Prematurely condensed chromosomes (PCCs) were induced at (A) $1 \mathrm{~h}$ and (B) $24 \mathrm{~h}$ following exposure to hyperthermia $\left(41^{\circ} \mathrm{C} 1 \mathrm{~h}\right)$, 4Gy of $\gamma$-radiation, or $\gamma$-radiation with prior exposure to hyperthermia $\left(41^{\circ} \mathrm{C}\right.$ $1 \mathrm{~h}$ ). Fig. $3 \mathrm{~A}$ is adapted from a previous study of ours (7). The means \pm SD of 3 separate experiments are presented. Between 500 and 600 PCC spreads were scored for each point. cont, control (unexposed cells); Ht 41, hyperthermia at $41^{\circ} \mathrm{C} ; 4 \mathrm{~Gy}$, radiation at $4 \mathrm{~Gy}$.
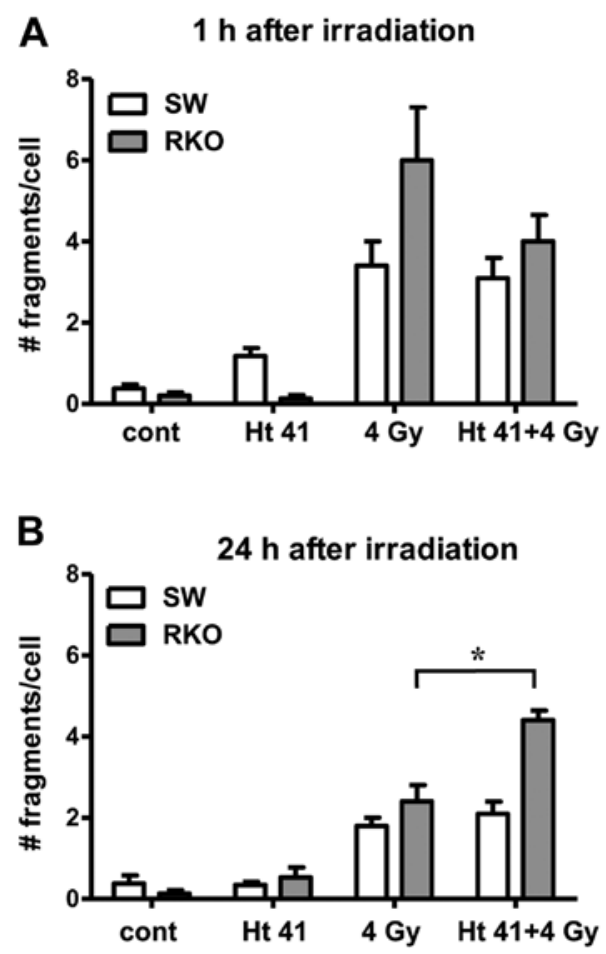

Figure 4. Frequency of chromosomal fragments in SW-1573 (chromosome 2) and RKO (Prematurely condensed chromosomes (PCCs) were induced at (A) $1 \mathrm{~h}$ and (B) $24 \mathrm{~h}$ following exposure to hyperthermia $\left(41^{\circ} \mathrm{C} 1 \mathrm{~h}\right), 4 \mathrm{~Gy}$ of $\gamma$-radiation or $\gamma$-radiation with prior exposure to hyperthermia $\left(41^{\circ} \mathrm{C} 1 \mathrm{~h}\right)$. Fig. 4A is adapted from a previous study of ours (7). Fig. 4B is adapted from a previous study of ours (12). The means \pm SD of 3 experiments are presented. Between 500 and 600 PCC spreads were scored for each point. cont, control (unexposed cells); $\mathrm{Ht} 41$, hyperthermia at $41^{\circ} \mathrm{C} ; 4 \mathrm{~Gy}$, radiation at $4 \mathrm{~Gy}$.
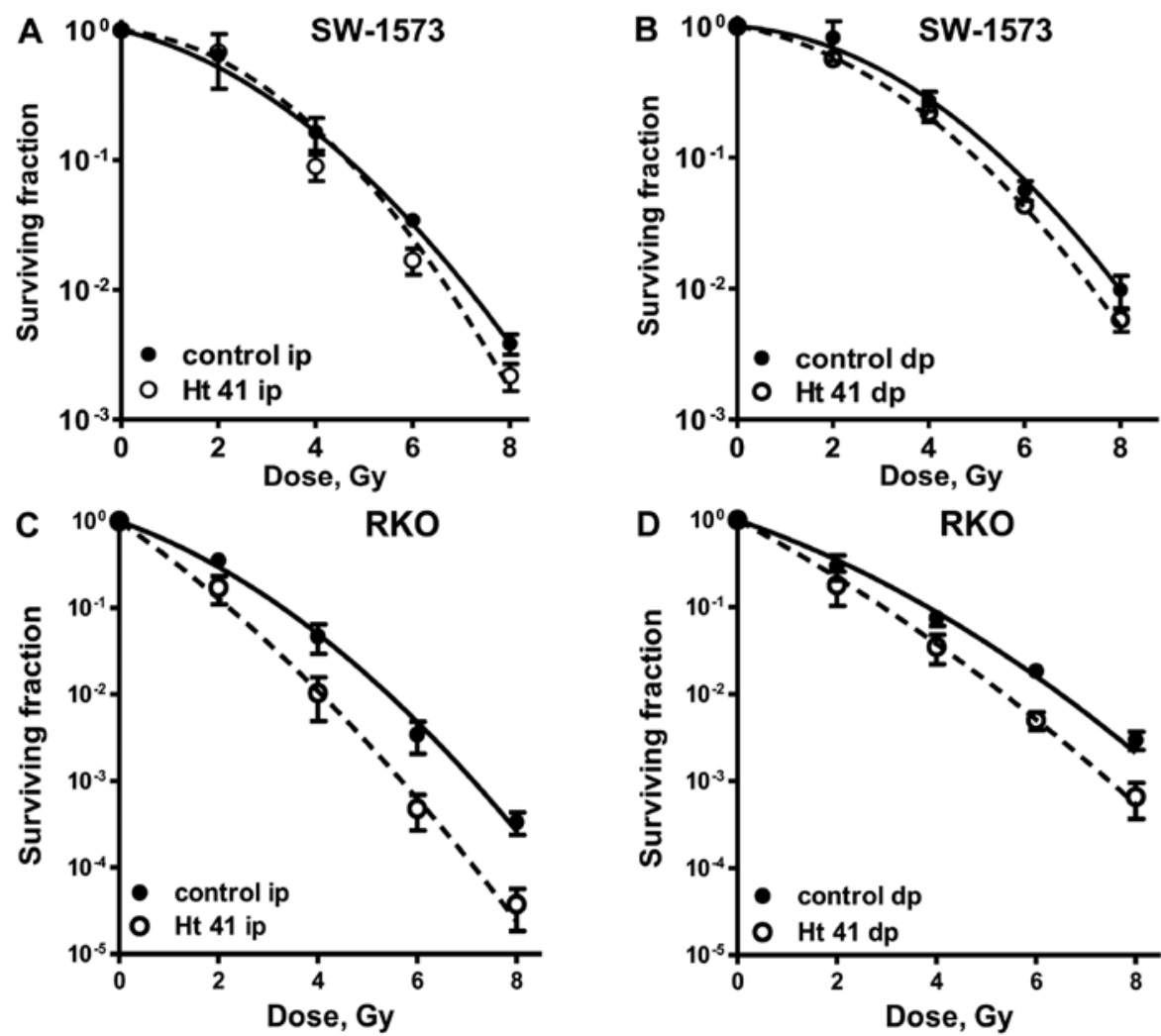

Figure 5. Radiation dose survival curves of confluent cultures of (A and B) SW-1573 and (C and D) RKO cells plated (A and C) $1 \mathrm{~h}$ after irradiation, ip or (B and D) $24 \mathrm{~h}$ after irradiation, dp with or without prior exposure to hyperthermia at $41^{\circ} \mathrm{C}$ for $1 \mathrm{~h}$. The means $\pm \mathrm{SEM}$ of at least 3 experiments are shown. 
Table I. Effect of hyperthermia on LQ parameters $\alpha$ and $\beta$, the hyperthermia $\alpha$-enhancement factor and $\beta$-enhancement factor and the PLDR- $\alpha$ and PLDR- $\beta$ in SW-1573 and RKO cells.

\begin{tabular}{|c|c|c|c|c|c|c|}
\hline \multirow[b]{2}{*}{ Cell line } & \multicolumn{6}{|c|}{ LQ parameter } \\
\hline & $\alpha\left(\mathrm{Gy}^{-1}\right)$ & $\beta\left(\mathrm{Gy}^{-2}\right)$ & $\alpha-E F$ & $\beta$-EF & PLDR- $\alpha$ & PLDR- $\beta$ \\
\hline SW-1573 ip & $0.21 \pm 0.02$ & $0.06 \pm 0.02$ & & & & \\
\hline SW1573 41 ip & $0.06 \pm 0.02$ & $0.11 \pm 0.03$ & $0.3 \pm 0.2$ & $1.8 \pm 0.8$ & & \\
\hline SW-1573 dp & $0.09 \pm 0.02$ & $0.06 \pm 0.02$ & & & $2.3 \pm 0.6$ & $1.0 \pm 0.5$ \\
\hline SW-1573 $41 \mathrm{dp}$ & $0.05 \pm 0.02$ & $0.08 \pm 0.02$ & $0.6 \pm 0.2$ & $1.3 \pm 0.5$ & $1.2 \pm 1.1$ & $1.4 \pm 0.5$ \\
\hline RKO ip & $0.55 \pm 0.09$ & $0.02 \pm 0.01$ & & & & \\
\hline RKO 41 ip & $0.80 \pm 0.09$ & $0.05 \pm 0.02$ & $1.5 \pm 0.5$ & $2.5 \pm 1.3$ & & \\
\hline RKO dp & $0.47 \pm 0.09$ & $0.01 \pm 0.01$ & & & $1.2 \pm 0.3$ & $2.0 \pm 1.4$ \\
\hline RKO $41 \mathrm{dp}$ & $0.64 \pm 0.11$ & $0.05 \pm 0.02$ & $1.4 \pm 0.4$ & $5.0 \pm 2.5$ & $1.3 \pm 0.3$ & $1.0 \pm 0.2$ \\
\hline
\end{tabular}

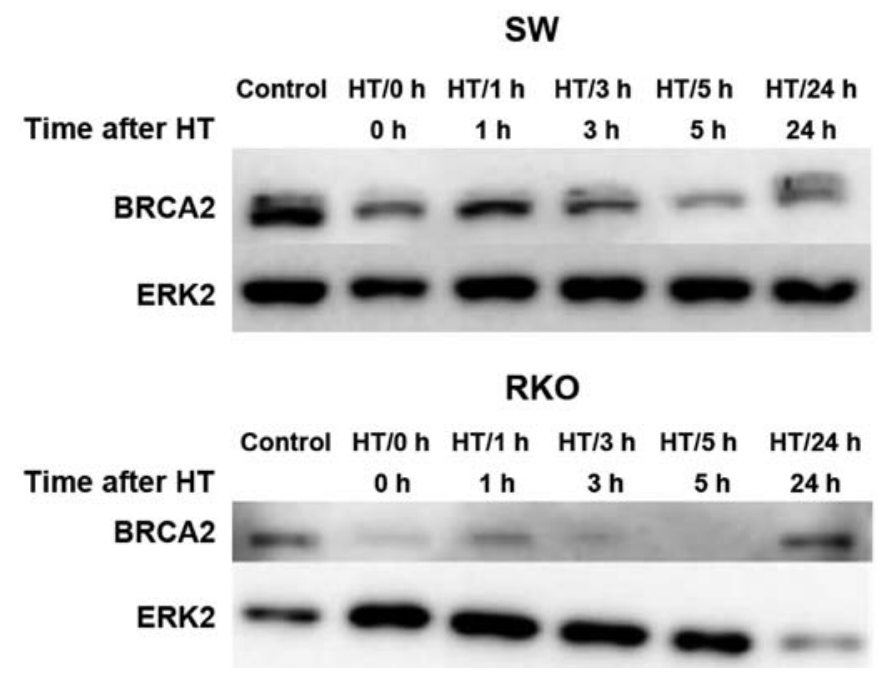

Figure 6. Western blot analyses of SW-1573 (SW) and RKO cells at 0-5 and $24 \mathrm{~h}$ following exposure to hyperthermia at $41^{\circ} \mathrm{C}$ for $1 \mathrm{~h}$. Control, unexposed cells; RT, radiation, HT, hyperthermia.

in the SW-1573 cells, the BRCA2 levels following exposure to hyperthermia were somewhat lower than in the unexposed control cells. At $24 \mathrm{~h}$, the BRCA2 levels returned levels similar to those of the controls.

Induction of apoptosis following the exposure of SW-1573 and RKO cells to hyperthermia and radiation. Nicoletti assay was performed to explore the effects of apoptosis following exposure to hyperthermia combined with exposure to radiation. At $1 \mathrm{~h}$ after exposure, no apoptotic DNA fragments were detected in both the RKO and SW-1573 cells (Fig. 7). In the RKO cells, exposure to hyperthermia alone induced apoptosis in 5\% of the population at $24 \mathrm{~h}$ after exposure (Fig. 7B). Following combined exposure to hyperthermia and radiation, apoptosis increased to approximately $20 \%$. In the SW- 1573 cells, on the other hand, apoptosis hardly played a role in exposure-induced cell death (Fig. 7A).
A

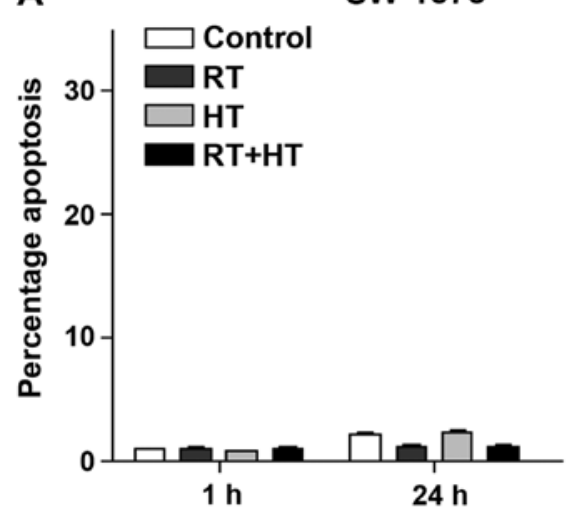

B

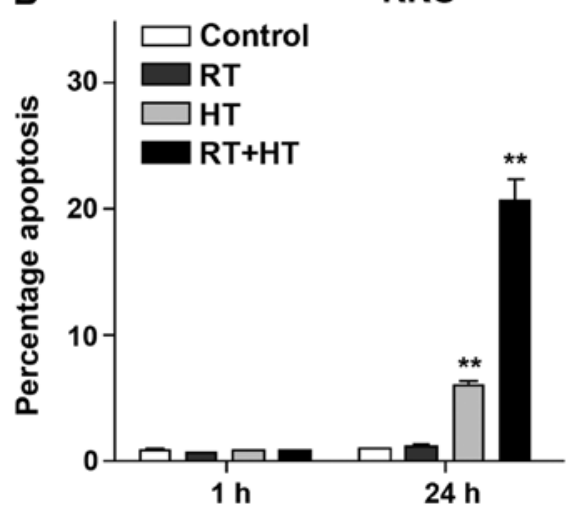

Figure 7. Mean percentages of apoptosis at 1 and $24 \mathrm{~h}$ following exposure in (A) SW-1573 and (B) RKO cells. Results are presented as the means \pm SD; * $\mathrm{p}<0.05$ as compared to control (unexposed cells). RT, radiation, HT, hyperthermia.

\section{Discussion}

Hyperthermia is a very potent radio- and chemosensitizer, that can already be effective at mild temperatures (30-36). Hyperthermia is therefore often applied as adjuvant anticancer 
therapy (37). Heat may interfere with the normal IR-induced signaling required for chromosomal DNA DSB repair, thus resulting in increased cellular radiosensitivity (37). However, it has been described that hyperthermia alone at $42-48^{\circ} \mathrm{C}$ for 30-120 min also induces genotoxic effects in human A549 cells (6). The increased frequency of micronuclei was only found following exposure at $45^{\circ} \mathrm{C}$ or at higher temperatures. Bergs et al (7) showed that pre-exposure to mild hyperthermia increased the frequency of radiation-induced chromosomal translocation.

In the present study, we showed that although exposure to mild hyperthermia for $1 \mathrm{~h}$ at $41^{\circ} \mathrm{C}$ prior to exposure to radiation increased the frequency of translocations at $1 \mathrm{~h}$ after exposure, these genotoxic effects were not further enhanced at $24 \mathrm{~h}$ after exposure. At this time-point, the frequency of translocations following combined exposure was even lower than after 4 Gy alone. Translocations result from the erroneous rejoining of chromosomal fragments by DNA repair processes. It was suggested by El-Awady et al (10) that hyperthermia inhibits the rejoining of correct chromosome ends, leading to an increased frequency of chromosomal fragments and increases the probability of DNA DSB misrepair $(10,12)$ shortly after exposure. That this effect is not augmented at $24 \mathrm{~h}$ after exposure is in agreement with the temporary hyperthermia-induced inhibition of HR which lasts for up to $6 \mathrm{~h}$ (3). This corresponds well with our observation in this study, that the BRCA2 protein levels were decreased as compared to the control cells for up to $5 \mathrm{~h}$ after exposure. At $24 \mathrm{~h}$ after exposure, BRCA2 could be detected again in both cell lines. In the SW-1573 cells, the effect of hyperthermia on BRCA2 was less clear than in the RKO cells. The RKO cells were radiosensitized by exposure to hyperthermia for $1 \mathrm{~h}$ at $41^{\circ} \mathrm{C}$, and the $\mathrm{SW}-1573$ cells were not radiosensitized. However, the lower number of chromosomal translocations found at $24 \mathrm{~h}$ after combined exposure may also be caused by cell death. As mainly G2 PCCs were studied, chromatid breaks were expected as well. These were observed, although the numbers were insufficient to quantify. This may be due to the PCC calyculin technique which made the accurate determination of the aberration type not possible. This was acknowledged earlier by Coco-Martin and Begg (38), who also studied chemically-induced PCCs with FISH. Moreover, we also observed that exposure to hyperthermia induced chromatin conformational changes, so that the resolution became lower.

It has been demonstrated that hyperthermia has differential effects on the LQ parameters of SW-1573 and RKO cells $(31,32)$. In the thermosensitive RKO cells $(31,32)$, hyperthermia clearly increased the values of $\alpha$ and $\beta$, for cells plated immediately and delayed after exposure. In the less thermosensitive SW-1573 cells $(31,32)$ on the other hand, pre-exposure to hyperthermia only increased the value of $\beta$. These findings indicate that exposure to hyperthermia for $1 \mathrm{~h}$ at $41^{\circ} \mathrm{C}$ sensitizes $\mathrm{RKO}$ cells at low and high radiation doses and that SW-1573 cells are only sensitized after high doses of radiation $(31,32)$. The ability of mild temperature (in the range of $40-42^{\circ} \mathrm{C}$ ) hyperthermia to increase the radiosensitivity of human tumor cells has been shown to be cell line-dependent (33). This effect is also dependent on the capability of the cell to repair DNA damage following combined exposure to hyperthermia and radiation $(34,35)$. The relation between cell survival and chromosomal aberrations following combined exposure remains unclear, as only the RKO cells were radiosensitized at this temperature and the dynamics of translocation frequencies are about similar.

Furthermore, we showed that when the cells were plated at $24 \mathrm{~h}$ after exposure, the survival levels were higher than when the cells were plated directly after treatment. The repair of potentially lethal damage after radiation, which is responsible for the higher survival levels after delayed plating as compared to immediate plating is a well-known phenomenon $(17,39)$. This was also demonstrated by the lower values of the LQ parameters after delayed plating as compared to these values for immediately plated cells. The significantly lower frequency of chromosomal fragments in both cell lines at $24 \mathrm{~h}$ after irradiation alone as compared to $1 \mathrm{~h}$ after exposure correlates well with the repair of potentially lethal damage. However, following combined exposure, in the RKO cells, the frequency of chromosomal fragments remained at the level found at $1 \mathrm{~h}$ after exposure. This may be due to the induction of apoptosis which was not observed in the SW-1573 cells. In the SW-1573 cells, no difference in fragment frequency was found between exposure to radiation alone and combined exposure. From this it was concluded that apoptosis, which may be induced by chromosomal damage or depletion of the BRCA 2 protein, is at least partly responsible for the hyperthermia-induced radiosensitization of RKO cells. This was also observed by Tomita (8) who stated that when DNA is not repaired or is misrepaired following combined exposure to radiation and hyperthermia, cells undergo apoptosis. There remains however, a discrepancy between the apoptosis and chromosomal aberration studies, as apoptosis can be examined on the whole cell population, while chromosomal aberrations using PCC cannot be performed on the S-phase cell population.

Radiosensitization induced by exposure to hyperthermia at a temperature of $41^{\circ} \mathrm{C}$ was observed in the RKO cells, but was only very modest in the SW-1573 cells. Chromosomal translocations were probably not responsible for this sensitization, as the induction of translocations following exposure to radiation alone and combined exposure followed the same trend in both cell lines. This has been described earlier by Tucker et al (40).

In conclusion, our findings indicate that the increase in the translocation frequency observed at $1 \mathrm{~h}$ following combined exposure to hyperthermia and radiation is not present at $24 \mathrm{~h}$. Exposure to hyperthermia increased the death of RKO cells, and this was at least partly due to apoptosis. The repair of potentially lethal damage, as shown by the decrease in chromosomal aberrations at $24 \mathrm{~h}$ as compared to $1 \mathrm{~h}$ after exposure is responsible for the higher survival levels after delayed plating.

\section{Acknowledgements}

We gratefully thank the Maurits and Anne de Cock and the Nijbakker Morra Foundations for providing the fluorescence microscopes with the software for scoring chromosomal aberrations. The Stichting Vanderes and the Dutch Cancer Society (nos. UVA 2008-4019 and UVA 2012-5540) are acknowledged for personnel financial support.

\section{References}

1. Oei AL, Vriend LEM, Crezee J, Franken NA and Prawczyk PM: Effects of hyperthermia on DNA repair pathways: one treatment to inhibit them all Rad Onc 10: 65, 2015. 
2. Baeyens A, Thierens H, Claes K, Poppe B, de Ridder L and Vral A: Chromosomal radiosensitivity in BRCA1 and BRCA2 mutation carriers. Int J Radiat Biol 80: 745-756, 2004

3. Krawczyk PM, Eppink B, Essers J, Stap J, Rodermond H, Odijk H, Zelensky A, van Bree C, Stalpers LJ, Buist MR, et al: Mild hyperthermia inhibits homologous recombination, induces BRCA2 degradation, and sensitizes cancer cells to poly (ADP-ribose) polymerase-1 inhibition. Proc Natl Acad Sci USA 108: 98519856, 2011

4. Allen $\mathrm{C}$, Halbrook $\mathrm{J}$ and Nickoloff JA: Interactive competition between homologous recombination and non-homologous end joining. Mol Cancer Res 1: 913-920, 2003.

5. Kass EM and Jasin M: Collaboration and competition between DNA double-strand break repair pathways. FEBS Lett 584: 3703-3708, 2010.

6. Speit G and Schütz P: Hyperthermia-induced genotoxic effects in human A549 cells. Mutat Res 747-748: 1-5, 2013.

7. Bergs JW, Krawczyk PM,BorovskiT, ten Cate R, Rodermond HM, Stap J, Medema JP, Haveman J, Essers J, van Bree C, et al: Inhibition of homologous recombination by hyperthermia shunts early double strand break repair to non-homologous end-joining. DNA Repair (Amst) 12: 38-45, 2013.

8. Tomita M: Involvement of DNA-PK and ATM in radiation- and heat-induced DNA damage recognition and apoptotic cell death J Radiat Res (Tokyo) 51: 493-501, 2010

9. Kampinga HH, Dynlacht JR and Dikomey E: Mechanism of radiosensitization by hyperthermia ( $>$ or $=43$ degrees $C$ ) as derived from studies with DNA repair defective mutant cell lines. Int J Hyperthermia 20: 131-139, 2004

10. El-Awady RA, Dikomey E and Dahm-Daphi J: Heat effects on DNA repair after ionising radiation: Hyperthermia commonly increases the number of non-repaired double-strand breaks and structural rearrangements. Nucleic Acids Res 29: 1960-1966, 2001.

11. Dahm-Daphi J, Brammer I and Dikomey E: Heat effects on the repair of DNA double-strand breaks in CHO cells. Int J Radiat Biol 72: 171-179, 1997.

12. Bergs JW, ten Cate R, Haveman J, Medema JP, Franken NA and van Bree C: Chromosome fragments have the potential to predict hyperthermia-induced radio-sensitization in two different human tumor cell lines. J Radiat Res (Tokyo) 49: 465-472, 2008.

13. Dewey WC, Sapareto SA and Betten DA: Hyperthermic radiosensitization of synchronous Chinese hamster cells: Relationship between lethality and chromosomal aberrations. Radiat Res 76 : 48-59, 1978.

14. Gotoh E, Asakawa I and Kosaka H: Inhibition of protein serine/threonine phosphatases directly induces premature chromosome condensation in mammalian somatic cells. Biomed Res 16: 63-68, 1995.

15. Barendsen GW: Dose fractionation, dose rate and iso-effect relationships for normal tissue responses. Int J Radiat Oncol Biol Phys 8: 1981-1997, 1982.

16. Barendsen GW, Van Bree C and Franken NA: Importance of cell proliferative state and potentially lethal damage repair on radiation effectiveness: Implications for combined tumor treatments (Review). Int J Oncol 19: 247-256, 2001.

17. Barendsen GW: The relationships between RBE and LET for different types of lethal damage in mammalian cells: Biophysical and molecular mechanisms. Radiat Res 139: 257-270, 1994.

18. Franken NA, Van Bree C, Veltmaat MA, Rodermond HM, Haveman J and Barendsen GW: Radiosensitization by bromodeoxyuridine and hyperthermia: Analysis of linear and quadratic parameters of radiation survival curves of two human tumor cell lines. J Radiat Res (Tokyo) 42: 179-190, 2001.

19. Franken N, Vanbree C, Streefkerk J, Kuper I, Rodermond H, Kipp J, Haveman J and Barendsen G: Radiosensitization by iodo-deoxyuridine in cultured SW-1573 human lung tumor cells. Oncol Rep 4: 1073-1076, 1997.

20. Franken NA, van Bree C, Veltmaat MA, Ludwików G, Kipp JB and Barendsen GW: Increased chromosome exchange frequencies in iodo-deoxyuridine-sensitized human SW-1573 cells after $\gamma$-irradiation. Oncol Rep 6: 59-63, 1999.

21. Bergs JW, Franken NAP, ten Cate R, van Bree C and Haveman J: Effects of cisplatin and gamma-irradiation on cell survival, the induction of chromosomal aberrations and apoptosis in SW-1573 cells. Mutat Res 594: 148-154, 2006

22. Franken NA, van Bree $\mathrm{C}$, ten Cate $\mathrm{R}$, van Oven $\mathrm{CH}$ and Haveman J: Importance of TP53 and RB in the repair of potentially lethal damage and induction of color junctions after exposure to ionizing radiation. Radiat Res 158: 707-714, 2002.
23. Castro Kreder N, Van Bree C, Franken NAP and Haveman J: Colour junctions as predictors of radiosensitivity: X-irradiation combined with gemcitabine in a lung carcinoma cell line. J Cancer Res Clin Oncol 129: 597-603, 2003.

24. Franken NA, Rodermond HM, Stap J, Haveman J and van Bree C: Clonogenic assay of cells in vitro. Nat Protoc 1: 2315-2319, 2006

25. Franken NA, Ruurs P, Ludwików G, van Bree C, Kipp JB Darroudi F and Barendsen GW: Correlation between cell reproductive death and chromosome aberrations assessed by FISH for low and high doses of radiation and sensitization by iodo-deoxyuridine in human SW-1573 cells. Int J Radiat Biol 75: 293-299, 1999.

26. Franken NA, ten Cate R, Krawczyk PM, Stap J, Haveman J, Aten J and Barendsen GW: Comparison of RBE values of high-LET $\alpha$-particles for the induction of DNA-DSBs, chromosome aberrations and cell reproductive death. Radiat Oncol 6: 64, 2011.

27. Franken NA, Hovingh S, Ten Cate R, Krawczyk P, Stap J, Hoebe R, Aten J and Barendsen GW: Relative biological effectiveness of high linear energy transfer $\alpha$-particles for the induction of DNA-double-strand breaks, chromosome aberrations and reproductive cell death in SW-1573 lung tumour cells. Oncol Rep 27: 769-774, 2012.

28. van Bree C, Franken NA, Rodermond HM, Stalpers LJ and Haveman J: Repair of potentially lethal damage does not depend on functional TP53 in human glioblastoma cells. Radiat Res 161: 511-516, 2004.

29. Riccardi C and Nicoletti I: Analysis of apoptosis by propidium iodide staining and flow cytometry. Nat Protoc 1: 1458-1461, 2006.

30. Bergs JW, Franken NA, Haveman J, Geijsen ED, Crezee J and van Bree C: Hyperthermia, cisplatin and radiation trimodality treatment: A promising cancer treatment? A review from preclinical studies to clinical application. Int J Hyperthermia 23: 329-341, 2007

31. Franken NA and Barendsen GW: Enhancement of radiation effectiveness by hyperthermia and incorporation of halogenated pyrimidines at low radiation doses as compared with high doses: Implications for mechanisms. Int J Radiat Biol 90: 313-317, 2014

32. Franken NA, Oei AL, Kok HP, Rodermond HM, Sminia P, Crezee J, Stalpers LJ and Barendsen GW: Cell survival and radiosensitisation: Modulation of the linear and quadratic parameters of the LQ model (Review). Int J Oncol 42: 1501-1515, 2013.

33. Xu M, Myerson RJ, Straube WL, Moros EG, Lagroye I, Wang LL, Lee JT and Roti Roti JL: Radiosensitization of heat resistant human tumour cells by 1 hour at 41.1 degrees $C$ and its effect on DNA repair. Int J Hyperthermia 18: 385-403, 2002.

34. Xu M, Wright WD, Higashikubo R, Wang LL and Roti Roti JL: Thermal radiosensitization of human tumour cell lines with different sensitivities to 41.1 degrees C. Int J Hyperthermia 15: 279-290, 1999.

35. Xu M, Myerson RJ, Xia Y, Whitehead T, Moros EG, Straube WL and Roti JL: The effects of 41 degrees C hyperthermia on the DNA repair protein, MRE11, correlate with radiosensitization in four human tumor cell lines. Int J Hyperthermia 23: 343-351, 2007.

36. Kok HP, Crezee J, Franken NA, Stalpers LJ, Barendsen GW and Bel A: Quantifying the combined effect of radiation therapy and hyperthermia in terms of equivalent dose distributions. Int $\mathrm{J}$ Radiat Oncol Biol Phys 88: 739-745, 2014.

37. Hunt CR, Pandita RK, Laszlo A, Higashikubo R, Agarwal M, Kitamura T, Gupta A, Rief N, Horikoshi N, Baskaran R, et al: Hyperthermia activates a subset of ataxia-telangiectasia mutated effectors independent of DNA strand breaks and heat shock protein 70 status. Cancer Res 67: 3010-3017, 2007.

38. Coco-Martin JM and Begg AC: Detection of radiation-induced chromosome aberrations using fluorescence in situ hybridization in drug-induced premature chromosome condensations of tumour cell lines with different radiosensitivities. Int J Radiat Biol 71: 265-273, 1997.

39. Franken NA, Van Bree CV, Kipp JB and Barendsen GW: Modification of potentially lethal damage in irradiated Chinese hamster V79 cells after incorporation of halogenated pyrimidines. Int J Radiat Biol 72: 101-109, 1997.

40. Tucker JD, Cofield J, Matsumoto K, Ramsey MJ and Freeman DC: Persistence of chromosome aberrations following acute radiation: I, PAINT translocations, dicentrics, rings, fragments, and insertions. Environ Mol Mutagen 45: 229-248, 2005. 